\title{
DISSECTING FOURTH PERSON POINT OF VIEW IN GAME DESIGN
}

\author{
Dini Faisal ${ }^{1}$, San $\mathrm{Ahdi}^{2}$, Hendra Afriwan ${ }^{3}$ \\ 1,2,3 Desain Komunikasi Visual, Fakultas Bahasa dan Seni, Universitas Negeri Padang \\ dinifaisal@fbs.unp.ac.id ${ }^{1}$, sandesigncomm@gmail.com ${ }^{2}$, hendrafriwandkv@gmail.com ${ }^{3}$
}

\begin{abstract}
Abstrak
Point of view dalam desain game erat kaitannya dengan karakter, visualisasi, dan kamera. Seperti first person point of view dimana pemain menjadi karakter dalam game dengan penggunaan kamera yang memperlihatkan perspektif dari karakter game yang dimainkan. Third person point of view yaitu pemain mengontrol karakter sehingga penggunaan kamera memperlihatkan karakter yang dikontrol dan interaksinya dengan environment game. Dua point of view itu adalah point of view yang dikenal dalam desain game. Jika pemain bisa menjadi dan mengontrol karakter, bagaimana jika pemain tidak bisa menjadi maupun mengontrol karakter?. Karakteristik ini disebut sebagai fourth person point of view, istilah yang pertama kali digunakan oleh game Pavilion dalam materi promosinya. Adapun tujuan dari penelitian ini adalah untuk membahas karakteristik permainan fourth person point of view, dan perbandingannya dengan point of view lainnya. Penelitian ini merupakan penelitian studi kasus yang membahas mengenai game Pavilion dengan teknik pengumpulan data berupa play-testing game, wawancara dan studi pustaka. Hasil penelitian menunjukkan bahwa point of view dalam game memiliki kaitan dengan genre dan style game. Pada studi kasus game Pavilion karakteristik fourth person point of view dapat digunakan karena game tidak berfokus pada eksplorasi cerita dan karakter.
\end{abstract}

Kata kunci: fourth person point of view, game design, game Pavilion

\begin{abstract}
Point of view in game design is closely related to character, visualization, and use of in-game cameras. First person point of view means that the player becomes the character in the game, and the camera only shows the perspective from the character's eyes. The meaning of the third person point of view is the player controls the character, the camera shows the character entirely so the player can see how the character interacts within the environment. These two points of view are basically known in game design. If a player can become and control a character, what if the player cannot become or control the character? This characteristic is called as the fourth person point of view, the term that was first used by game Pavilion in its promotional material. The purpose of this research is to discuss the characteristics of the fourth person point of view, and the comparison with another point of view. This is a case study research that discusses the Pavilion game with data collection techniques through play-testing the game, interviews, and literature studies. The result of the study shows that the point of view in the game has to do with genre and game style. Moreover, the case study of game Pavilion shows that its characteristic of fourth person point of view is appropriate because the game does not focus on the exploration of story and character.
\end{abstract}

Keywords: fourth person point of view, game design, game Pavilion 


\section{PENDAHULUAN}

Istilah sudut pandang atau sudut penggambaran (point of view / POV) yang dikenal selama ini yaitu sudut pandang orang pertama (first person point of view), sudut pandang orang kedua (second person point of view) dan sudut pandang orang ketiga (third person point of view) yang bisa ditemukan dalam karya sastra, film dan juga game. Dalam game, point of view yang dikenal ada dua, yaitu first person point of view dan third person point of view.

First person point of view dalam game kemudian juga dikenal sebagai salah satu genre permainan game seperti fisrt person shooter. Meskipun demikian, point of view tidak hanya sekedar merujuk pada genre game, tapi point of view merujuk pada penggunaan kamera dan visualisasi game yang tampak pada layar. Penggunaan kamera dalam game bisa diartikan sebagai visualisasi atau perspektif yang tampak dari karakter yang dimainkan (Haigh-hutchinson, 2005; Laurier \& Reeves, 2014; Zammitto, 2008) dan visualisasi atau perspektif karakter yang dimainkan. Pada umumnya game mainstream yang dikeluarkan oleh developer game ternama akan merujuk pada penggunaan kamera berdasarkan point of view di atas.

Pada tahun 2014 sebuah game indie berjudul Pavilion dipasarkan ke publik untuk konsol game PS4. Hal yang menarik dari game indie ini adalah penggunaan istilah fourth person game untuk menggambarkan game ini. Pavilion merupakan puzzle game yang dibuat oleh Vissiontrick media dengan tim developer oleh Rickard Westman dan Henrik Flink. Pavilion pertama kali dipublish untuk PC dan konsol PS4 dan telah memenangkan berbagai jenis penghargaan, yaitu: Winner Best Design AZPlay 2015, Winner Best Art Big Fest 2016, Official selection Indiecade 2015, Grand Prix Busan Indie Connect 2015, Nominee Best Game Big Fest 2016 dan Finalist Nordic Game Indie Night 2015. Game pavilion sendiri merupakan game indie-istilah indie game (independent games) sendiri tidak memiliki definisi yang pasti karena akademisi game cenderung untuk membahas "bagaimana" konsep indie game ketimbang "apa" itu indie game (Parker, 2013)-yang dapat dipahami sebagai marketing (pemasaran), style (gaya), dan orisinalitas game.

Artikel yang dibuat oleh McWhertor (2013) menjelaskan bahwa menurut desainernya, game Pavilion merupakan game petualangan dengan menggunakan perspektif orang ke empat. Pemain berinteraksi dengan objek seperti lonceng, lampu, dan kotak untuk mengarahkan karakter game. Karakter dalam game, seorang pria dengan latar belakang dan tujuan permainan yang misterius, tidak bisa dikontrol secara langsung oleh pemain, pemain hanya bisa mengarahkan karakter dengan berinteraksi dengan benda-benda disekitar karakter.

Istilah fourth person point of view merupakan istilah yang baru baik dalam industri game maupun dalam karya sastra dan film. Beberapa penelitian mengenai point of view dan penggunaan kamera dalam game telah dilakukan oleh Haigh-hutchinson, 2005; Laurier, Eric. Reeves, 2014; Morgan, 2016; Zammitto, 2008, tetapi sejauh ini hanya meneliti mengenai first person dan third person point of view, ataupun mengenai penggunaan kamera dalam game. Penelitian yang penulis lakukan adalah meneliti mengenai fourth 
person point of view yang diperkenalkan oleh game Pavilion dengan menggunakan game tersebut sebagai studi kasus dalam memahami sudut pandang orang keempat. Tujuan penelitian ini adalah untuk memahami pengertian fourth person point of view dengan menbandingkannya dengan point of view lainnya, serta menganalisis karakteristik dari fourth person point of view game Pavilion.

\section{METODE PENELITIAN}

Penelitian ini merupakan penelitian studi kasus dengan menggunakan game Pavilion sebagai kasus yang akan dianalisis. Dalam penelitian studi kasus, peneliti bisa menggunakan berbagai metode dalam menjelaskan atau mengevaluasi suatu fenomena (Sumartono, 2017). Adapun metode penelitian yang digunakan dalam penelitian ini adalah kualitatif deskriptif dimana peneliti akan mengeksplorasi game Pavilion dengan mengumpulkan informasi secara detail.

Penelitian ini dilaksanakan dengan melakukan tahapan play-testing terhadap game digital fourth person puzzle game yang berjudul "Pavilion". Berdasarkan hasil playtesting yang dilakukan maka peneliti bisa memahami secara mendalam mengenai desain interaktivitas game, environment game, interaksi pemain dengan karakter yang nantinya akan mengarahkan ke hasil penelitian. Sejalan dengan itu peneliti akan melakukan studi pustaka terhadap penelitian dan artikel ilmiah yang akan mendukung data peneliti. Selain mencobakan permainan secara langsung, peneliti juga melakukan studi di youtube dan membaca review pemain mengenai Pavilion. Langkah selanjutnya yaitu melakukan wawancara dengan informan dari akademisi desain game, praktisi di bidang game dan pemain game. Wawancara tersebut berguna untuk penunjang data dan sekaligus menghasilkan keabsahan data peneliti.

Wawancara dilakukan dengan cara tatap muka langsung. Informan terlebih dahulu diminta untuk memainkan game Pavilion yang menjadi objek penelitian, kemudian peneliti akan memberikan pertanyaan semi terstruktur seputar game tersebut, pemahaman mengenai sudut pandang permainan, karakter game, gameplay, environment game. Adapun akademisi yang menjadi informan terdiri dari empat orang akademisi, tiga diantaranya merupakan akademisi dibidang desain game dan satu akademisi dari sastra. Keputusan pemilihan akademisi dari dua bidang ilmu ini adalah untuk mendapatkan data yang lebih akurat mengenai penggunaan istilah point of view. Sedangkan informan dari praktisi game terdiri dari dua orang dan pemain game terdiri dari empat orang.

\section{HASIL DAN PEMBAHASAN}

\subsection{Point of View}

Pemahaman mengenai point of view salah satunya berkaitan dengan bagaimana kamera "menampilkan" gambar di layar permainan dan pemahaman mengenai sudut pandang dalam visual game yaitu bagaimana "kamera" digunakan dalam menangkap karakter dan background (Aumont, 2009). Pemahaman mengenai kamera dalam game akan berbeda dengan kamera dalam film, karena ada beberapa teknik kamera dalam film yang tidak bisa diterapkan dalam game (Lin, Shih, \& Tsai, 2004). 
Penggunaan kamera dan visualisasi dalam game berpengaruh terhadap immersion, presence, dan enggagement ketika pemain memainkan sebuah game. Perbedaan point of view dalam game akan memberikan efek immersion, presence dan enggagement yang berbeda pula bagi pemain (McMahan, 2003). Immersion dan presence dapat diartikan sebagai keterpikatan dan kekhusyukan pemain dalam memainkan game yang diakibatkan oleh rasa keterlibatan pemain yang seolah-olah berada dalam dunia game. Sedangkan enggagement dapat diartikan sebagai "emotional investment" pemain dalam memainkan game. Perkembangan visual dan juga kamera game dari 2D dan isometric camera menjadi 3D membuat immersion, presence dan engagement pemain dalam memainkan game menjadi lebih kuat. Hal ini tidak mengherankan karena peralihan visual game dari 2 dimensi menjadi 3 dimensi dan penggunaan kamera dalam game dapat menciptakan sensasi "keterlibatan secara nyata" bagi pemainnya, yang kemudian dapat membuat pemain ketagihan bahkan lupa waktu ketika bermain.

First person point of view yaitu dimana pemain menjadi karakter yang ada dalam game, sehingga secara visual yang tampak pada layar adalah apa yang dilihat melalui mata karakter yang dimainkan (Haigh-hutchinson, 2005). Pada permainan game dengan sudut pandang orang pertama yang terlihat hanyalah background atau environment dimana karakter berada, sedangkan visual dari karakter tidak akan terlihat. Third person point of view yaitu dimana pemain mengontrol karakter, sehingga secara visual yang tampak pada layar adalah karakter yang dikontrol berikut background atau environment dimana karakter tersebut berada (Lim \& Reeves, 2009). Sehingga pada permainan dengan sudut pandang orang ketiga akan memperlihatkan interaksi antara karakter yang dikontrol dengan lingkungan atau environment dalam game.

Agar bisa memahami point of view lebih lanjut ada baiknya kita pahami juga point of view dalam media yang berbeda seperti karya sastra. Game dan karya sastra menggunakan dua media yang berbeda sehingga penggunaan atau pemahaman sudut pandang pun bisa berbeda. Penggambaran sudut pandang dalam karya sastra terdiri dari first person point of view, second person point of view dan third person point of view. Sedangkan pada game hanya mengenal fist person point of view, third person point of view, dan sekarang fourth person point of view yang akan dibahas lebih lanjut dalam studi kasus game Pavilion.

Jika pada sudut pandang orang pertama dalam karya sastra narator menceritakan mengenai dirinya sendiri maka pada game orang pertama, pemain menjadi karakter. Jika pada karya sastra karakter "aku" tersurat dalam teks cerita, maka sebaliknya pada game karakter "aku" atau karakter yang dimainkan oleh pemain tidak akan terlihat secara visual. Namun, pada dasarnya memiliki pemahaman yang sama bahwa cerita atau game menceritakan mengenai pengalaman "aku" atau pemain sebagai tokoh utama dalam cerita atau game.

Sedangkan dalam game orang ketiga, karakter yang dimainkan oleh pemain terlihat di layar secara visual karena pada sudut pandang ini pemain tidak lagi menjadi karakter, sehingga kamera atau sudut pengambilan gambar tidak berasal dari karakter, tetapi 
kamera justru mengambil gambar karakter atau memperlihatkan karakter yang dikontrol oleh pemain. Maka "aku" atau narator dalam sastra dan pemain yang mengontrol karakter berada di luar layar, yang terlihat hanya karakter yang dimainkan atau diceritakan.

Bagaimana ketika karakter yang ada dalam game tidak bisa dikontrol oleh pemain, atau pemain tidak bisa menjadi karakter dalam game, seperti dalam penggambaran orang pertama dan orang ketiga? Inilah yang kemudian disebut sebagai sudut pandang orang keempat atau fourth person point of view berdasarkan studi kasus game Pavilion. Sudut pandang orang keempat menurut developer game Pavilion adalah dimana karakter tidak bisa dimainkan secara langsung oleh pemain. Berbeda dengan permainan orang pertama dimana pemain "menjadi" karakter dan sudut pandang orang ketiga dimana pemain "mengontrol" karakter maka orang keempat dimana pemain tidak bisa menjadi dan mengontrol karakter tapi hanya bisa mengarahkan karakter dalam game dengan mengontrol elemen pendukung environment game.

Berdasarkan wawancara dengan informan dari akademisi dari bidang ilmu sastra, ia meragukan kemungkinan sudut pandang orang keempat dalam karya sastra. Namun, hal yang berbeda mungkin saja muncul dalam game yang diakibatkan oleh perbedaan media yang digunakan seperti teks dan gambar. Lebih lanjut kita bahas mengenai game fourth person dengan studi kasus game Pavilion.

\subsection{Game Pavilion}

Game Pavilion merupakan puzzle game adventure dimana pemain mengarahkan karakter dalam game menjelajahi suatu taman atau tempat dengan setting alternative realm. Puzzle game adventure merupakan pencampuran dari dua genre game, yaitu puzzle dan adventure. Puzzle game pada umumnya tidak replayable (tidak dapat dimainkan berulang) karena tidak adanya faktor acak (randomness) dalam permainan puzzle (Schell, 2008). Selain itu Schell juga menjelaskan bahwa pada umumnya permainan puzzle memiliki satu strategi kunci untuk menyelesaikan permainan dan tujuan permainan adalah untuk menemukan strategi tersebut. Sedangkan adventure game merupakan game yang berfokus pada cerita dan eksplorasi cerita oleh pemain. Adventure game juga memiliki pemecahan teka-teki (puzzle solving) yang terintegrasi dalam ceritanya (Chess, 2015; Fernández-Vara, 2011).

Tujuan permainan Pavilion merupakan suatu misteri yang akan terpecahkan dengan memainkan dan menyelesaikan permainan. Pemain tidak dikenalkan dengan karakter, latar belakang karakter, apa yang harus dilakukan karakter dan mengapa karakter harus berkeliling menjelajahi dunia game Pavilion tersebut. Secara kontrol permainan dan gameplay pun pemain tidak diberi tutorial cara bermain sehingga cerita, tujuan permainan dan cara bermain menjadi satu misteri besar yang harus dipecahkan sendiri oleh pemain dari awal. Dalam hal "cara bermain" pemain harus mencari tahu sendiri dengan melakukan eksperimen atau mencobakan langsung. Bagian awal game sebaiknya dapat membuat pemain memahami dan mempelajari cara bermain (Oxland, 2004), tetapi tutorial dalam game bukanlah suatu keharusan, karena pemain akan 
menemukan cara bermain dengan mencoba game (Mikami, personal communication, 10 September 2018). Namun, game seperti ini cenderung hanya diperuntukkan untuk kelompok pemain tertentu yang memang menyukai genre game puzzle dan misteri.

Berbeda dengan game digital lainnya dimana pemain seolah-olah menjadi karakter yang dimainkan dalam game, karakter dalam Pavilion tidak bisa dimainkan oleh pemain, melainkan hanya bisa diarahkan dengan menggerakkan benda-benda yang ada di environment game. Inilah yang kemudian disebut sebagai permainan orang keempat, dimana pemain tidak bisa menjadi karakter ataupun mengontrol karakter.

Environment game Pavilion mengambil setting alternative realm dilihat dari visualnya yang cenderung terlihat surealis dengan adanya pencampuran antara teknologi dengan alam dan struktur bangunan dalam ukuran sangat besar. Setting alternative realm sendiri memiliki kekurangan dan kelebihan. Kelebihannya yaitu dari sisi desainer game dapat mengeksplorasi bentuk dan membuat konsep kreatif yang tidak biasa yang tidak biasa kita temukan secara real-life atau pada kehidupan nyata. Dari sisi pemain, keunggulannya yaitu pemain bisa mengeksplorasi lingkungan dan visual yang indah dan tidak biasa tadi, sehingga pemain bisa "berkhayal" dan berandai mengenai dunia alternatif ini. Kekurangan dari setting alternative realm ini yaitu tidak relatable karena setting dan visual tersebut tidak ada di kehidupan nyata. Namun, alternative realm justru bisa menjadi positif apabila setting alternatif dan surealis tersebut masih relevan dengan kehidupan nyata.

Fungsi visual dalam permainan yang disebut dengan environment game ini bukan hanya sekedar indah untuk dipandang, tapi juga menjadi penanda. Berdasarkan wawancara dengan Mikami, elemen dari environment game biasanya bisa dibedakan mana bagian yang interaktif dan mana bagian yang tidak interaktif. Elemen tersebut biasanya bisa dibedakan dengan warna dan detail gambar. Elemen yang tidak interaktif biasanya warnanya menyatu dengan background atau latar belakang permainan dan detailnya pun cenderung sederhana sehingga tidak terlihat mencolok. Sebaliknya elemen yang interaktif warnanya cenderung lebih terang dan detailnya pun cenderung lebih jelas terlihat sehingga elemen tersebut lebih menonjol dibandingkan elemen lainnya. Biasanya elemen yang menonjol ini merupakan tanda bagi pemain untuk menyentuh (jika permainannya berupa sentuh atau klik jika menggunakan kursor) sebagai bagian dari interaksi permainan.

Namun, pada beberapa stage di game Pavilion, elemen interaktif dan non-interaktif tidak terlihat berbeda sehingga ketika memainkan game tersebut pemain cenderung salah menyentuh elemen yang non-interaktif karena berfikir elemen tersebut akan memberikan reaksi permainan. Peneliti menyimpulkan bahwa ini diakibatkan oleh ilustrasi dari environment game sangat detail meskipun dalam ukuran yang lebih kecil. Secara umum visual environment-nya terlihat sangat bagus dan detail tapi dari segi interaktivitas justru sedikit mengganggu karena pemain tidak bisa memisahkan elemen interaktif dan non-interaktif. 


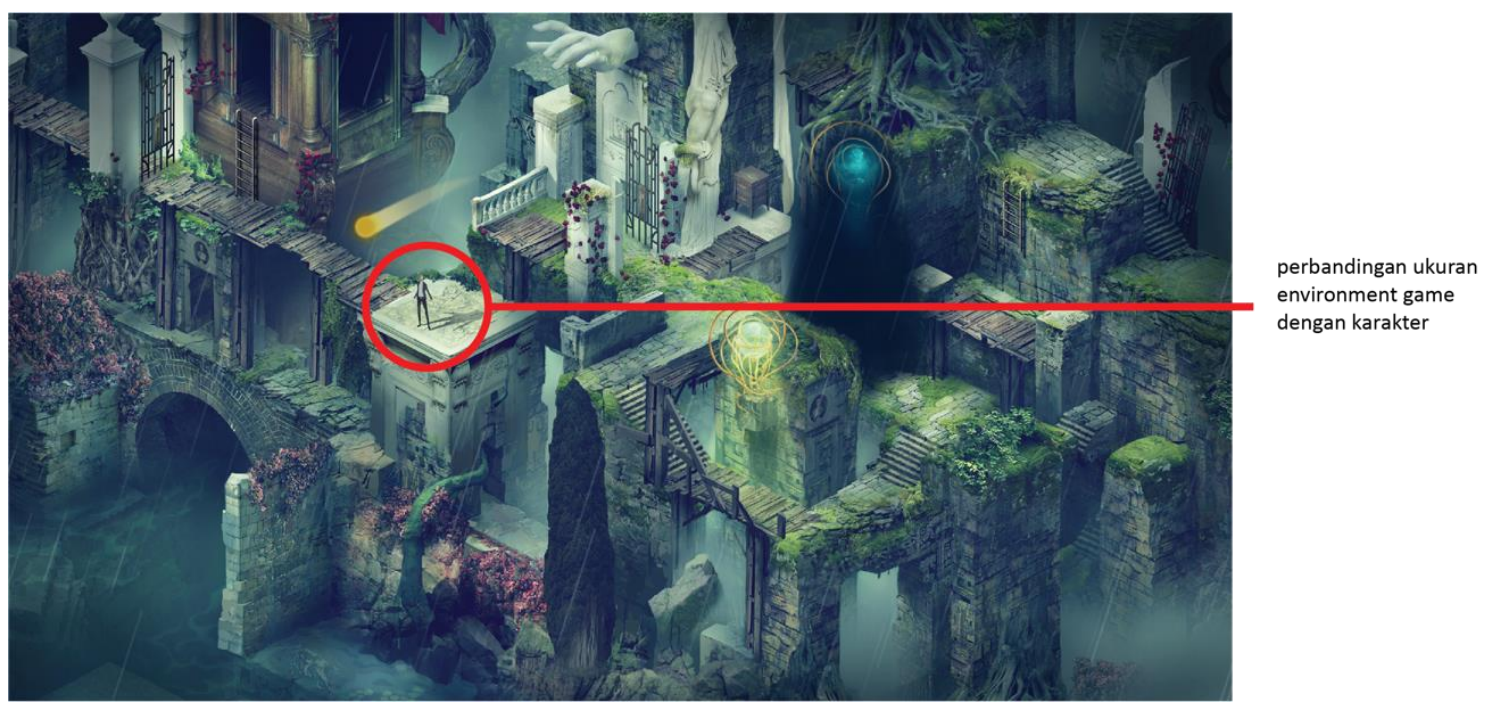

Gambar 1. Visual environment game Pavilion dengan menggunakan isometric camera

Penggambaran environment game menggunakan isometric camera, yaitu penggambaran tampilan layar permainan dengan bentuk perspektif $3 / 4$. Tampilan seperti ini dapat memperlihatkan lingkungan permainan secara utuh, namun kekurangannya pemain cenderung kesulitan untuk memahami letak atau arah atas dan bawah dan pemain juga tidak bisa melakukan eksplorasi terhadap environment karena isometric camera merupakan tipe fixed camera. Pada dasarnya isometric camera mengurangi "sense of immersion" atau rasa terpikat dan menyatu dalam permainan.

Kekurangan lain dari perspektif isometric ini yaitu penggambaran karakter yang kecil dibandingkan proporsi lingkungan game seperti yang terlihat dari gambar 1 , sehingga jika dimainkan sebagai mobile game di smartphone maka pemain akan kesulitan melihat pergerakan dari karakter karena ukurannya yang cenderung kecil. Namun, jika kita pahami penjelasan di sub bagian sebelumnya kita bisa mengkaitkan antara karakter yang tidak bisa dikontrol atau pemain yang tidak bisa menjadi karakter dengan penggambaran environment menggunakan isometric camera. Keduanya memperlihatkan bahwa karakter bukanlah hal yang penting dalam game ini, mengingat ukuran karakter yang kecil dibandingkan dengan keseluruhan environment dalam layar dan karakter yang tidak bisa dimainkan. Sehingga pada game ini pemain tidak merasakan immersion karena konsep game yang tidak mementingkan karakter.

\subsection{Fourth Person dalam Game Pavilion}

Karakter dalam permainan ini tidak diperlihatkan secara jelas (kecuali dalam materi promosi seperti poster). Berdasarkan analisis peneliti ini disebabkan oleh sudut pandang orang keempat tersebut, dimana "pemain tidak bisa mengontrol karakter" sehingga tidak ada rasa kedekatan antara pemain dan karakter. Berbeda dengan permainan orang pertama dimana pemain "menjadi" karakter dan permainan orang ketiga dimana pemain "mengontrol" karakter, sehingga ada rasa dekat dengan karakter dalam game. Ketika pemain tidak bisa menjadi dan mengontrol karakter maka karakter menjadi tidak penting bagi pemain, sehingga sepanjang permainan kita tidak bisa melihat karakter 
secara jelas. Seperti yang telah dijelaskan pada sub bagian sebelumnya bahwa karakter tidak diketahui latar belakang, cerita dan motivasinya dalam permainan. Hal ini semakin memperkuat kesan bahwa karakter tidak penting dalam permainan ini, dan bisa disimpulkan bahwa karakter tidak penting karena pemain tidak bisa menjadi ataupun mengontrol karakter. Namun, misteri yang timbul akibat pertanyaan-pertanyaan seputar karakter justru semakin memperkuat efek misteri dari genre petualangan game ini.

Argumen bahwa karakter tidak penting diperkuat dengan pembahasan dari penggambaran environment game yang menggunakan isometric camera, dimana isometric camera lebih menekankan pada penggambaran environment secara utuh, sehingga, detail karakter pun menjadi tidak penting. Environment game diperlihatkan dengan detail bahkan pada bagian yang tidak diperlukan. Pada sub bab sebelumnya sudah dibahas mengenai elemen yang digambarkan secara detail adalah elemen interaktif dan elemen yang tidak detail adalah elemen yang non-interaktif. Hanya saja game Pavilion menggambarkan enviroment secara detail. Ini memperkuat argumen dimana, pada game ini environment menjadi lebih penting dibandingkan karakter.

Sehingga pemain hanya ingin memecahkan misteri permainan, tidak berfokus pada karakter atau pengembangan cerita, sehingga genre puzzle seperti ini cocok menggunakan point of view orang keempat.

Tabel 1. Analisis perbandingan point of view berdasarkan interaksi, karakter dan environment

\begin{tabular}{|l|l|l|l|}
\hline & \multicolumn{1}{|c|}{$\mathbf{1}^{\text {st }}$ Point of View } & \multicolumn{1}{|c|}{$\mathbf{3}^{\text {rd }}$ Point of View } & $\mathbf{4}^{\text {th }}$ Point of View \\
\hline $\begin{array}{l}\text { Karakter / } \\
\text { avatar }\end{array}$ & Tidak terlihat di layar & Terlihat di layar & Terlihat di layar \\
\hline $\begin{array}{l}\text { Visuasi } \\
\text { tubuh karakter/avatar. }\end{array}$ & $\begin{array}{l}\text { Tidak terlihat/ hanya } \\
\text { tangan/sebagian dari }\end{array}$ & $\begin{array}{l}\text { Terlihat karakter } \\
\text { secara utuh di layar, } \\
\text { pada umumnya di } \\
\text { visualisasikan di } \\
\text { depan kamera } \\
\text { sehingga hanya } \\
\text { terlihat tubuh } \\
\text { belakang karakter }\end{array}$ & $\begin{array}{l}\text { Terlihat karakter } \\
\text { secara utuh, } \\
\text { visualisasi dari } \\
\text { depan. }\end{array}$ \\
\hline $\begin{array}{l}\text { kamera } \\
\text { tubspective view: }\end{array}$ & $\begin{array}{l}\text { Perspective view: } \\
\text { kamera mengikuti } \\
\text { karakter yang } \\
\text { kamera, menggerakkan } \\
\text { karakter berarti } \\
\text { menggerakkan kamera. } \\
\text { digerakkan ke atas, } \\
\text { bawah, kiri dan kanan }\end{array}$ & $\begin{array}{l}\text { Isometric } \\
\text { camera/fixed } \\
\text { camera }\end{array}$ \\
\hline $\begin{array}{l}\text { Interaksi } \\
\text { pemain dan } \\
\text { karakter } \\
\text { permainan }\end{array}$ & $\begin{array}{l}\text { Pemain menjadi } \\
\text { karakter }\end{array}$ & $\begin{array}{l}\text { Pemain mengontrol } \\
\text { karakter }\end{array}$ & $\begin{array}{l}\text { Pemain tidak bisa } \\
\text { menjadi dan } \\
\text { mengontrol } \\
\text { karakter }\end{array}$ \\
\hline
\end{tabular}




\begin{tabular}{|c|c|c|c|}
\hline & $1^{\text {st }}$ Point of View & $3^{\text {rd }}$ Point of View & $4^{\text {th }}$ Point of View \\
\hline $\begin{array}{l}\text { Immersion, } \\
\text { presence, } \\
\text { engagement }\end{array}$ & $\begin{array}{l}\text { Dekat/terbangun } \\
\text { dengan baik }\end{array}$ & $\begin{array}{l}\text { Dekat/terbangun } \\
\text { dengan baik }\end{array}$ & $\begin{array}{l}\text { Tidak dekat/tidak } \\
\text { terbangun } \\
\text { dengan baik }\end{array}$ \\
\hline $\begin{array}{l}\text { Perbandingan } \\
\text { karakter vs } \\
\text { environment }\end{array}$ & $\begin{array}{l}\text { Perbandingan tidak } \\
\text { kontras, karena } \\
\text { environment yang bisa } \\
\text { dilihat terbatas seperti } \\
\text { sudut pandang } \\
\text { manusia normal di } \\
\text { kehidupan nyata, } \\
\text { karena tujuan game } \\
\text { untuk fokus pada } \\
\text { environment dan } \\
\text { bukan karakter }\end{array}$ & $\begin{array}{l}\text { Perbandingan tidak } \\
\text { kontras, } \\
\text { memperlihatkan } \\
\text { karakter yang } \\
\text { dimainkan dan } \\
\text { environment karena } \\
\text { karakter dan } \\
\text { environment menjadi } \\
\text { fokus dalam } \\
\text { permainan }\end{array}$ & $\begin{array}{l}\text { Perbandingan } \\
\text { ukuran karakter } \\
\text { dan environment } \\
\text { sangat kontras. } \\
\text { Environment } \\
\text { diperlihatkan } \\
\text { secara luas (wide) } \\
\text { sehingga ukuran } \\
\text { karakter dalam } \\
\text { layer menjadi } \\
\text { sangat kecil. } \\
\text { Disebabkan oleh } \\
\text { fokus pemain ada } \\
\text { di environment } \\
\text { dan bukan } \\
\text { karakter }\end{array}$ \\
\hline $\begin{array}{l}\text { Latar } \\
\text { belakang } \\
\text { karakter/ } \\
\text { background } \\
\text { story }\end{array}$ & Penting/diceritakan & Penting/diceritakan & $\begin{array}{l}\text { Tidak } \\
\text { penting/tidak } \\
\text { diceritakan }\end{array}$ \\
\hline
\end{tabular}

Perbedaan ketiga point of view tersebut erat kaitannya dengan genre permainan karena akan mempengaruhi desain game seperti desain karakter, environment dan interaktivitas dalam game. Permainan yang berfokus pada karakter permainan akan memiliki avatar dan akan diperlihatkan menggunakan first person point of view atau third person point of view. Penggambaran di layar komputer atau sudut pengambilan gambar (kamera) pada first person point of view akan lebih banyak berfokus pada environment dalam game, dikarenakan first person point of view dimana pemain menjadi karakter. Sedangkan pada third person point of view, penggambaran di layar atau penggunaan kamera akan fokus pada karakter dan environment karena akan memperlihatkan interaksi karakter dalam environment game. Begitu juga pada permainan Pavilion dengan menggunakan fourth person point of view memperlihatkan karakter dan environment, tetapi dengan perbedaan ukuran yang sangat kontras. Environment divisualisasikan dalam ukuran luas (wide) sehingga karakter yang ditempatkan dalam environment menjadi sangat kecil ukurannya. Hal ini juga dipengaruhi oleh penggambaran environment dalam game Pavilion tersebut yaitu dengan menggunakan isometric camera dimana karakter dari isometric camera adalah visual environment yang luas (wide). 
Jika dilihat dari pemahaman mengenai fourth person point of view dan karakteristik fourth person point of view berdasarkan studi kasus game pavilion dapat disimpulkan bahwa, interaksi pemain, karakter, environment dan genre permainan tidak dapat menciptakan sense of immersion, presence dan engagement yang kuat.

\section{KESIMPULAN}

Istilah fourth person point of view atau sudut pandang orang keempat merupakan istilah yang baru dan dicetus dan pertama kali digunakan oleh game digital berjudul Pavilion. Game Pavilion yang pertama kali dipasarkan pada tahun 2014 pada konsol permainan PS4 dan dipasarkan ulang sebagai permainan digital di smartphone pada tahun 2017. Pavilion merupakan game indie, yaitu game dipasarkan tidak melalui publisher atau perusahan ternama atau yang sudah mapan secara ekonomi dan bisnis.

Game pavilion memiliki genre puzzle game dan adventure game. Genre gabungan semacam ini sangat sering dijumpai dalam game saat ini. Berdasarkan penelitian terhadap studi kasus dari game Pavilion ini peneliti menyimpulkan bahwa genre game akan mempengaruhi point of view dalam game karena berkaitan dengan tema/style game, karakter dan penggambaran kamera. Game dengan point of view yang berbeda akan memberikan pengalaman bermain yang berbeda karena style game, karakter, environment akan mempengaruhi gameplay dan interaksi pemain dengan game.

Pada studi kasus game pavilion yang merupakan genre puzzle adventure dengan visual secara isometric camera berhasil diterjemahkan atau divisualisasikan menggunakan karakteristik fourth person point of view. Ini disebabkan karena pada fourth person point of view pemain tidak bisa menjadi dan mengontrol karakter sehingga interaksi pemain dengan karakter tidak memiliki kedekatan emosional. Pada genre puzzle adventure terutama pada studi kasus Pavilion lebih berfokus pada pemecahan masalah secara environment game sehingga karakter tidak berpengaruh dalam permainan ini. Ada atau tidaknya karakter tidak akan memberikan dampak yang besar terutama karena dalam game ini background story atau latar belakang karakter tidak diceritakan, bahkan tujuan dari karakter pun tidak diketahui sepanjang permainan.

Peneliti menyimpulkan bahwa permainan Pavilion fourth person point of view ini memiliki kaitan dengan status game tersebut sebagai indie game atau independent games, dimana kelompok atau desainer indie games memiliki peluang lebih besar dalam melakukan eksplorasi mengenai genre game, gameplay, visual game bahkan point of view dalam game. Berdasarkan pemahaman mengenai fourth person point of view melalui studi kasus game Pavilion dapat disimpulkan bahwa permainan dengan karakteristik fourth person point of view memungkinkan jika tujuan atau konsep dari game tidak berfokus pada eksplorasi cerita atau karakter. 


\section{DAFTAR PUSTAKA}

Aumont, J. (2009). The point of view. Querterly Review of Film and Video, (January 2015), 37-41.

Chess, S. (2015). The Ravenhearst video games and gothic appropriation. Feminist Media Studies, 15(3), 382-396.

Fernández-Vara, C. (2011). From open mailbox to context mechanics: shifting levels of abstraction in adventure games. In FDG '11 Proceedings of the 6th International Conference on Foundations of Digital Games (pp. 131-138).

Haigh-hutchinson, M. (2005). Fundamentals of Real-Time Camera Design.

Laurier, E., \& Reeves, S. (2014). Cameras in video games: Comparing play in CounterStrike and the Doctor Who Adventures.

Lim, S., \& Reeves, B. (2009). Being in the Game : Effects of Avatar Choice and Point of View on Psychophysiological Responses During Play Being in the Game : Effects of Avatar Choice and Point of View on Psychophysiological Responses During Play. Media Psychology, (January 2015), 37-41.

Lin, T., Shih, Z., \& Tsai, Y. (2004). Cinematic Camera Control in 3D Computer Games. In WSCG SHORT Communication papers proceedings.

McMahan, A. (2003). Immersion, Engagement, and Presence.

Morgan, D. (2016). Where are we ?: camera movements and the problem of point of view. New Review of Film and Television Studies, 0309 (February).

Parker, F. (2013). Indie Game Studies Year Eleven. In Proceedings of DiGRA 2013: DeFragging Game Studies.

Schell, J. (2008). The art of game design. Burlington: Morgan Kaufmann Publisher.

Zammitto, V. (2008). Visualization techniques in video games. In EVA 2008 London Conference (pp. 267-276). 